\title{
PERCEPTIONS ON TEACHING PROFESSION AND CHANGING ROLE OF SCHOOL TEACHERS: AN INVESTIGATION FROM EIGHT SCHOOLS IN DUBAI AND SHARJAH
}

\section{Sahar Mahmoud El Ayouby and Solomon Arulraj David}

\author{
The British University in Dubai, the UAE \\ DOI: http://dx.doi.org/10.24327/ijrsr.2017.0804.0168
}

\section{ARTICLE INFO}

\section{Article History:}

Received $10^{\text {th }}$ January, 2017

Received in revised form $14^{\text {th }}$

February, 2017

Accepted 08 ${ }^{\text {th }}$ March, 2017

Published online $28^{\text {th }}$ April, 2017

\section{Key Words:}

Teacher Identity, Teacher Role, New Education Reforms and Teacher Role Change.

\begin{abstract}
The purpose of this study was to investigate the perceptions on teaching profession and on the changing role of school teachers in the United Arab Emirates (UAE) and to examine how this perception affects the teaching profession. To achieve this aim, one main question was inspected: Does the current perceptions of students, teachers and school leaders on teachers in the selected eight schools from Dubai and Sharjah affect the value of teaching profession? Dramatic changes on teacher's role over the last decades have challenged teachers' professional identities and carried the question of what it means to be a teacher in recent times. To articulate this change, some significant theories have been consulted in this study, such as professional identity, the role theory, the changing nature of the teacher's role, educational reforms and privatization of education. The study devises three groups of participants comprising 200 teachers, 262 students and 10 experienced educators from eight private and public schools. Multiple instruments were utilized in a mixed methods research to collect data. The study finds that teachers notice a big shift about how they are valued. The results showed that teacher satisfaction is most notably obtained by effectively changing students' attitudes in a positive way. The results also indicated that most students do not consider teaching as a future career despite their deep respect for their teachers. In addition, the results indicate that privatisation is key for the shift in the way teachers are valued.
\end{abstract}

Copyright ( ) Sahar Mahmoud El Ayouby and Solomon Arulraj David, 2017, this is an open-access article distributed under the terms of the Creative Commons Attribution License, which permits unrestricted use, distribution and reproduction in any medium, provided the original work is properly cited.

\section{INTRODUCTION}

Educators have played a significant role in shaping change in the Arab world in recent decades. Free education has been a significant tenant of the "social contract" in this region since independence (Akkari, 2004). At that time, teachers were regarded as the most respected group in society in the region. The role that teachers played at that time went beyond teaching towards sharing actively in the movement of innovation and modernism. Since the 1970s, the role of teachers has gradually become viewed differently. This change was associated with the dramatic economic and political fluctuations in the region. Since then, the debate around public education emerged (Farag, 1998) as public education system has faced many difficulties, in particular the ever-increasing number of new students (Akkari, 2004, p 145), lack of resources, the mixed-up and unrealistic strategies (Al-Taneiji, 2006) and corruption in the public sector (Institute for Anthropology and African Studies, 2008, p.6). Consequently, the quality of the education providedhas increasingly weakened and the teacher's role has progressively experienced a sort of constant erosion.

*Corresponding author: Sahar Mahmoud El Ayouby

The British University in Dubai, the UAE
Traditionally, most young Emirati children used to attend public primary and secondary schools, operated by Arab expatriate (Dubai School of Government, 2010). In the recent past, education has experienced constant change under the influence of globalization. This change implies a movement towards modernizing teaching techniques and allowinga partnership with the private sector. The newest wave of change started in 2005 when the Ministry of Education (MoE) 'delegated' the responsibility of education to the Abu Dhabi Educational Council, ADEC in Abu Dahbi and the Knowledge and Human Development Authority, KHDA in Dubai (Ibrahim, Al-Kaabi \& El-Zaatari, 2013). Since then, both authorities have implemented many initiatives to drive their agenda of change. However, many serious challenges still stand against the goal of building a modern educational system. One of the key difficulties was that the majority of teachers in the UAE are not citizens of the country (Ridge, 2006). Figures reveal that over $80 \%$ present of the male teachers in UAE schools are expatriate teachers (MoE, 2008). The second obstacle was the consistent inadequate performance and outcomes of the education system in the UAE (KHDA Annual Report, 2013). Furthermore, results have indicated the poor grades of UAE students in international exams, such as, TIMSS and PIZA (OECD, 2015). 
The main focus of this study was to apply the phonological method approach to add to the research body in this area by reviewing education reforms and their impacts in particular in Dubai and Sharjah schools. This study was directed by three hypotheses: That the change of the teacher's role in light of the literature review is a global phenomenon, Teachers in the study context demonstrate unsatisfactory spirits about their role and wellbeing, and the students view their teachers as unsatisfied and teaching as an unattractive profession. The study's main research question was to explore how the perceptions about teachers affect the value or standing of teachers in the UAE? Further the study explored on the following sub-questions: How is the teacher's role perceived by teachers and students in private and public schools in Dubai and Sharjah? And To what extent does the current teacher's role affect the status of a teacher in Dubai and Sharjah?

\section{Teacher Identity}

Exploring teachers' professional identity has risen as a distinct research field during the last two decades. To explain what this concept means, many writers have drawn on the meaning of identity in the social sciences. In their review for the relevant research on teachers' professional identity, during the period of 1988-2000, Beijaard, Meijer and Verloop (2003) introduced different definitions of professional identity based on how each study conceptualizes this notion. For instance, Samuel and Stephens (2000) have stated "professional identity is a "per located' understanding of a series of competing and sometimes contradictory values, behaviours, and attitudes grounded in the life experiences of the self in formation (Beijaard, Meijer and Verloop, 2003, p.122).In addition, they discussed the earlier work of (Mead, 1934 and Erikson, 1968 sited in Beijaard, Meijer and Verloop, 2003).

Erikson sketched a changing concept of identity. Identity is not a rigid construct, but something that improves during the entire life. Mead used the idea of identity in relationship with the idea of self; he explained how the self is established through connections with the environment. According to Mead, the self can rise only in a 'social setting'. The concept of identity is identified in several ways in the literature. The concept of professional identity is also defined in diverse ways in the area of teaching. In some studies, the concept of teacher identity is different from that of teachers' functional roles. Teacher identity is created on the central principles one has about teaching and being a teacher; principles that are constantly shaped and reshaped through an individual's involvement in different experiences (e.g. Mayer 1999; Zembylas 2005).

Zembylas argued that the teacher is an independent individual, frequently moving between two needs; the need to bond with other teachers and the need to keep a sense of originality. Not far from that understanding of teachers' identity, Hong (2010) studied the work of (Morgan, 2004 and Pavlenko, 2003) in which both emphasise the 'multi dimension' features of professional identity. Moreover, he argued that the manner in which we perceive ourselves impacts our intentions and judgments. In other studies of professional identity, the importance was placed on teachers' roles (e.g., Goodson \& Cole, 1994; Volkmann \& Anderson, 1998). Lasky (2005) uses a sociocultural theoretical lens to present teacher identity as a dynamic interaction between three constructs 'teacher identity, agency, and context'. Lasky argued that a teachers' sense of identity is formed as a result of this interaction. Therefore, it is clear that a teachers' professional identity has developed as a separate research subject. Yet, it is an area in which researchers abstract professional identity inversely, inspect varying issues within the framework of teachers' professional identity and as a result reach different goals.

\section{Teacher Role}

The area defining the role of the teacher was extensively highlighted in the literature of educational sociology as Waller (1932) presented the teacher as an 'institutional leader'. Since then, scholars have inspected teachers' roles through a variety of lenses. However, what is exactly meant by teacher role? This part of the study explores the body of literature on the definition of teacher role. The standard definition of the role describes it as a distinguished "set" of activities expected of a group of people in the exact social or structural positions (Turner, 2001). In addition, Turner suggested that there are possible inconsistencies. This conflict could be experienced through the various roles a teacher comprises in a classroom (Hargreaves, 2000). These factors can also be explored inside and outside the classroom, which lead this role to be a "demanding and complex task," as Harden \& Crosby (2000) described it and categorized it into six mixed roles; the teacher is: the information provider; the role model on the job; the facilitator; the curriculum evaluator; the course planer; and the resource material creator.

Along with theorizing teacher roles as sets of potentially conflicting tasks', role theorists realize that the views about teacher roles will change across time, and this will also impact the conditions and individuals, respectively (Turner, 2001).This feature was discussed earlier by (Waller, 1932 sited in Valli and Buese, 2007) who stated the role of a teacher is perceived by people in conjunction with the social situation. Thus, there can be a "kaleidoscopic shifting of roles" (Valli and Buese, 2007, p.3). In this regard, Role Theory explains roles by assuming that individuals are members of "social positions" and individuals hold anticipations for their own behaviours and other people's behaviour (Biddle, 1986). Both, Metz (1986) and recently Evans and Linda (2008) inspect the role conflict discovered earlier and integrate it to the new consideration of the role.

The conflict is reinforced as the expectations and responsibilities of the teachers grow, meanwhile their ability to influence the processes taking place within their campuses decline. Consequently, teachers in recent times assume 'semiprofessional statues' as they practice some autonomy over minor issues in the schools, but the power has shifted away from them to 'new professionalisms', such as administrators, managers and directors. Furthermore, some researchers concluded that teachers "Autonomy has evidently given way to accountability (Hoyle and Wallace, 2005, p. 100)." Obviously, the role theory has produced many studies and variances over the use of the role concept as it was adopted to explain several forms of social systems. To create a general definition of the role, four theory concepts were reviewed: consensus, conformity, role conflict, and role taking. 
The teacher role concept was also defined in multiple ways. Some have examined the teacher's role through the sociological research of teaching as an "occupation" (Lortie, 1975). Some have focused on the complex nature of the teaching profession (Wright, 1987). Wright (1987), for example, made the point that in any learning context, role is a complex factor. Cotterall (1995) claimed that the beliefs of students, parents and administrators about the teachers added more complexity to the teacher's role. Cotterall investigated the learners' beliefs regarding two potentially conflicting conceptualizations of the teacher's roles: the teacher as an authoritative figure or teacher as a learning facilitator. Others analysed the teacher's role as a dynamic profession that expands and grows differently as a result of new reforms. Bartlett and Ball (2004) both believed that reforms have created different roles for teachers and portray the new role of teachers as educational "entrepreneurs". As a result of the researchers' varied drives, the classification schemes used to theorize the teacher's role has resulted in creating distinguished, yet "overlapping dimensions" of the role (Valli and Buese, 2007). However, because the estimated goal of this study is to investigate the change in the teacher's role, the study believes that expectations for roles will vary across time and societies (Biddle, 1986).

\section{Impact of Educational Reforms}

Hargreaves and Goodson (2006) have identified 'five waves of reform' which formed the educational change and three phases of change during the last three decades: phases of 'optimism and innovation', 'complexity and contradiction', and 'standardization and marketization'. This seems to move beyond Hoyle's (1980) earlier notions that the new managerial set structures help to semi-professionalize teachers. Change for teachers has been anticipated through different approaches by Woods and Jeffrey (2002). Both argue that the ancient selfidentity or the 'original self-identity' of the teachers has been challenged during the restructuring of the education regime and that it was replaced by a 'substantial new identity'. However, trapped at the core of consecutive waves of reform, teachers have experienced their capacity and enthusiasm to behave as professionals negatively impacted (Evans and Linda, 2008).

There is extensive evidence of a de-professionalization and an erosion of the teacher's autonomy (Ingersoll, 2007). Education reform is a procedure. An essential factor of this change is the body of teachers. This part of the study will inspect the literature related to how reform has altered the teacher's identity and role. The teacher's work has experienced many innovations over the last three decades. Accordingly, the new instructional role was associated to teachers, particularly with the appearance of constructivism theory. The old portrayal of the teacher providing knowledge through root explanation, traditional strategy teaching and memorization has witnessed a forceful change. The teacher as an instructional coach or facilitator replaced the old teaching method (Finley, 2000).

\section{Teacher-Student Relationship}

The digital generation of students who experience real struggles to stay focused are easily distracted and hard to manage. This will simply develop a sense of opposition to the teachers. Consequently, students feel that their teachers are valid targets in expressing their own resistance and hostility.
Woods and Carlyle (2002) study the historical changes of the teacher's identity and they notice that during the 1970s and early 1980s, there appeared to be significant homogeneity between the "social identity and self-concept" among teachers. Since the restructuring reforms of recent decades the teacher's identity has become "less isomorphic", as teachers have become so stressful and started to lose confidence in their abilities to undertake the overlapping tasks they should perform.

\section{Teacher's Social Identity}

Many researchers have seen that installing privatization in education results in 'undermining' the teaching profession. For example, Hinchey and Kaplan (2005) debate that this process is going to lead to branding teachers as an almost out-dated group. From another perception, Ball (2003) argues that the regulation of these reforms will imply the use of new language to define roles and interactions. Learning is re-reduced as 'costeffective policy outcomes'; student achievement is a set of 'productivity targets' and teachers are re-operated as education manufacturers and are subject to consistent evaluation. Teachers are driven to re-create a new social identity, one based on individuality not unity, competence not association and anxiety not confidence.

\section{Emergence of the Private Market}

In an attempt to emphasise the role that new reforms play in education, several papers have highlighted performativity and accountability reforms, especially in relation to their impact on schools when adopting the methods and values of the private market. Several researchers such as Eurydice (1997), ERT (1995), Thélot and Vallet, (2000), Albouy and Wanecq, (2003), GERESE (2003), Nicaise et al. (2003), Johnstone (1998), IFC (1999), Patrinos, (1999), and Robertson et al. (2001) conclude the main evolutions of the new reform as: decentralization and deregulation in the field of management; radical slowdown in public expenditure in education to around $5 \%$ of GDP; shifting the focus of school programmes far from knowledge to more skills-oriented teaching; growing educational gap between higher and lower class children; emerging cooperation between schools and private companies and, lastly, education becoming itself a new money-making marketplace with all the interlaced aspects of private teaching, private schools and private management of schools; in one phrase: education business (Peter \&Jeferey, 2002; Marsh, 2002).

\section{Educational Reform in the United Arab Emirates}

Up to the end-1980s, almost all schooling in the UAE was provided by the MoE for all students. This free public education policy was restricted to citizens of the UAE only in the 1990s and other nationalities were not allowed to study in the public schools. The state decision stimulated the rapid expansion of private education as we acknowledge now. The private sector took all the advantages to invest increasingly by opening an excessive number of new schools that were significantly successful in promoting their programmes. Consequently, year after year the private sector has pulled the carpet away from formal education, even for the local students who have left government schools in increasing numbers to learn in international-based education. Essentially, 
implementing new reforms in education in the UAE has confused schools, as several reports have revealed, pushing many Emirati teachers to leave teaching or at least to request earlier retirement (Mansour, 2008).

\section{METHODOLOGY}

Both quantitative and qualitative researchers have extensively debated the validity of each design on answering a research question. However, Creswell argues that the feature of the research question energises the choice of methods (Creswell, 2013). According to (Caruth, 2013), the mixed method research has evolved in response to the limitations of both quantitative and qualitative strategies to answer the varied research purposes The primary benefit of the mixed method research (MMR) is that it allows the researcher to operate the strengths of both qualitative and quantitative research strategies (Creswell, 2009). In this study, the researcher has adopted mixed method research because the integration of both quantitative and qualitative methodologies is expected to provide the most appropriate approach to answer the questions of the study.

The research upon which this paper focuses was carried out during November-December 2015 in eight private and public schools. 200 teachers and 262 students responded to the quantitative component of the study. The teacher sample respondents were defined according to the demographic information of gender, age, qualification, for how long the respondent had worked in the current school, years of teaching, and school type. Of the total sample, $70 \%$ of the teachers were females and $30 \%$ were males. Likewise, the majority of students were female participants $(68.7 \%)$ and only one third were male students (31.3\%).Students from different backgrounds; ages and gender were chosen to increase the breadth of the sample and to reflect the real diversity of the student body in the UAE context. For the qualitative stage of the study, semi-structured interviews were utilized, and 10 contributors comprised the sample. The sample was initially selected based on the extensive experience of the interviewers to guarantee that those educators are able to add comprehensive insight to unpack the multiple dimensions of changes to the teacher's role.

An extensive review of the literature resulted in utilizing two instruments to collect data in two dimensions in the quantitative stage of the study: Teachers' survey, adopted from (Teacher 2000 Project questionnaire) and students' survey, adopted from ((MET project questionnaire). For the qualitative stage of the study: Semi-structured interviews were utilized to collect deep insights from a sample of experienced teachers and executives. The instruments were piloted for validity and reliability purposes. Various entities, including the researcher's academic supervisor, core subject teachers in two schools and subject coordinators reviewed the Teachers' questionnaire and it was re-written as presented previously. All respondents were informed of the nature of the research before they decided to take part and had the choice to partake or not. The permission to conduct the research was taken in each campus and the goal of the study was conveyed very clearly to the principals with a sample for each survey. Respondents were informed and assured that all resources used in the study would be confidential and that all their views were going to be used only for the purpose of the "scientific value" of the research.

\section{RESULTS, ANALYSIS AND DISCUSSION}

The object of this study was to determine if the current perception of teachers in the UAE impacts the value and image of the teacher's role. This part of the studywill represent the analysis of the quantitative and qualitative data gathered to exploreif there is a change in the way that the teachers viewed and to determine the degree to which the current perceptions of the teaching profession affect the value of a teacher in the UAE context.

\section{Teachers' QuestionnaireSunvey}

The purpose of this questionnaire was to reveal the perceptions of all teachers in the private and public schools $(\mathrm{N}=200)$ about the main aspects of the Teachers 2000 Study and to explore their self-appraisal of the changes encountered in the teacher's role. Results are demonstrated in eight sections: (A1) orientation to teaching, (A2) self-appraisal of teacher role, (A3) personal contribution and motivation, (A4) relations with students, (A5) relations with school administration, (A6) working environment, (A7) community role, and (A8) stress and work load.

A number of results emerged from the study; of most importance is 1: Proved change in the teacher's role. Teachers indicated that they see a change from the traditional role of a teacher. This theme was emphasized more strongly in the semistructured interviews. The second significant theme is theme 2: Teaching is not viewed as the future desired career for most students $(78 \%)$. Perceptions of female teachers were unlike their male peers, as the majority of female teachers said that they would re-choose teaching if they could plan their career again. The research showed specific areas of similarities and differences between the perception of male and female teachers. However, the overriding similarity was in result 3: The highest satisfying source for all teachers is changing students' attitudes in a positive way. Almost all female teachers $(95 \%)$ and most male teachers $(83 \%)$ indicated this fact. The findings in this study confirmed those documented in similar studies in Australia (Dinham and Scott, 1999, 2000a), Cyprus (Zembylas and Papanastasiou, 2006), Pakistan (Malik et al., 2011), and Malta (Vassallo, 2012).

\section{Students' QuestionnaireSunvey}

Student perceptions were explored through a questionnaire provided to middle and high school students from 8 schools in Dubai and Sharjah $(\mathrm{N}=262)$ with 82 boys and 180 girls. The questionnaire aimed to measure student perceptions of the teaching role of their teachers in the first part and to explore how they think about teachers in general in the second part. The students' responses were measured on a four-point Likert scale (never, sometimes, most times and always).

A large minority of students $(35 \%)$ believe that their teachers are doing great job most of the time. However, a large majority of students $(63 \%)$ indicate that they always respect their teachers' work. Only $30 \%$ of students perceive teachers 'work as some times comfortable, whereas the same percentage think their teachers' lives are good. Around half of the students 
indicate that they have never seen teachers invited to present on TV programmes. Most students $(75 \%)$ indicated that their parents never encourage them to be teachers and slightly more $(78 \%)$ stated that they would never like to be teachers in the future. It is worth noting in these results is the contradiction between the great respect that teachers have in their students perceptions, but at the same time teaching perceived as being a low-profile career.

\section{Qualitative Interview from Experienced Educators}

Experienced educators in participating schools were invited to take part in the qualitative study to support the previous quantitative data and gain deeper insights and ideas about the features of change and their impacts on teachers. Initially, experienced teachers were targeted for the semi-structured interviews due to their extensive knowledge about the situation of the teachers in the UAE education context. A number of themes emerged from the interviews

\section{Theme 1: Role Change}

Almost all the respondents indicated that the traditional teacher's role has changed and that the recent role of a teacher has different features than the one they used to experience when they were new teachers. A large majority of the teachers pronounced concerns about the change in attitude towards teachers, that whereas teachers in the past had more authority and power to deal with students, nowadays their hands are tied. Some indicated that the teacher's role is diminishing as a result of the increased interference from school administration and from parents. Experienced teachers used terms such as, big and great change to describe their spirits towards the change.

"It is like night and day. It has changed a lot; before teachers used to be like the owner of knowledge... he used to be like a master in the class room."

"Before being a teacher is like ... I mean this is a teacher everybody looks at him or her as a divine, a holy... teachers are now becoming just a way of delivering material for students."

\section{Theme 2: Change in Pedagogy}

Teachers were uneven in their views about new strategies of teaching, with a majority seeing that modern techniques are needed and that teachers' technological and strategic skills need to constantly be improved and updated. Few favour the old approach as teachers had much more control and confidence in commanding the classroom. Unlike in the past when the teacher was a principal provider of knowledge, nowadays, the student can get knowledge at the touch of a button on the internet.

"As teaching aiming for higher order skills, this has shifted the role of ownership of knowledge from the teacher, students own their learning now."

"Now we use the technology in presenting the lesson. But students do not concentrate because they depend in many resources not like the old time when the teacher was the only resource."

\section{Theme 3: Change in Teacher Value and Image}

The majority of the respondents feel that teachers were seen as highly respected individuals and that the teacher's role used to be much more involved in their students' lives. Some teachers feel that there is a negative societal stereotype which emphasises the idea that teachers are desperate and not very committed or motivated to teach. A large minority felt that the stereotype of the teacher's position still maintained its respectful standing in society, especially with educated parents. Other participants see that teachers themselves contribute to the misconception of the teacher's role because of several reasons.

The teacher will be blamed for any single mistake... That means the weakness vertex of the triangle, wherein the triangle consists of teachers, students and parents... The weakness point is the teacher.

"The image is very bad. My students do not believe me when I say that I chose to be a teacher since I was in grade 7they got shocked."

\section{Theme 4: Teaching is Unattractive Profession}

Many teachers indicated that the profession has lost its ability to attract young people to be interested in having a career as a teacher. The impact of new job roles becomes blurred and the teacher ends up being burdened with a plethora of responsibilities, low salaries, a lack of job security and appreciation.

"I told my sons do not [go] to this career because really [you] are suffering alot with low salaries, no motivation, no promotions. I am sorry to say this but now my son's salary is more than mine."

"Most of the teachers do not know the psychology of this new generation and all the time they have misunderstandings with students."

"People they do not want to work like teachers. It is not easy to have all of this in your shoulders.”

\section{Theme 5: Privatization}

This was a contentious issue, as $60 \%$ of respondents felt that privatization had a negative effect on the way the teacher is perceived. As education is for hire, the teacher is seen as purchasable, which creates a conflict that has adverse effects on the teacher-student relationship. Some teachers pointed out that as a result of privatization, more female teachers are hired as they tend to accept lower pay. Therefore, the number of male teachers is significantly lower than female teachers. Others feel that public school teachers tend to have more control over their classrooms as they get paid by the government so there is no conflict of interest.On the contrary, $30 \%$ of respondents felt that the presence of private schools in the market was to their advantage as it ensured a consistent demand for teachers. They also felt that it did not matter which system, public or private, they worked in. What mattered was the teacher's personal skills and ability to handle the responsibilities that this role entails.

"In public schools the goal is not collecting money it is more focusedon building the students but in the private organization it is to make money not to create a good citizen."

"Private means money means I can buy everything"

\section{CONCLUSION}

The findings of this study make a sole contribution to the search of teachers' attitudes about their role in a developing country. By investigating the elements of the changing teacher's role, a profound understanding of how teaching is practiced in the UAE was achieved. The following are the key findings of the study; 
- Teachers in the UAE clearly acknowledged the change of the teacher's role and they expressed some concerns linked with the continual reform cycles in the education system.

- Educators seem to originate a sense of 'value and worth' from their capacity to contribute to the community through making a difference in students' attitudes and lives.

- Deep disappointments are found linked with school administration, lack of recognition and teachers' 'lack of a voice' in the decision-making.

- The students' rating of their teachers' instructional and educational role was positive in general. Teachers still have the capacity to provide an effective teaching quality.

- A kind of mental stereotype of teachers was found. Teachers are respected for the role they play but at the same time they are seen as a group of people who work hard in uncomfortable and stressful conditions.

- Neither parents nor kids believe that teaching would be a desired career in the future.

- Based on the study's, the following recommendations are made for further studies.

- Organizing the relationship between the schools and teachers should be regulated and structured by the highest education authority in the country;

- Exploring and considering teachers and school administration views closely is crucial to collect valid data about the schools and to create direct links for the teachers to express their concerns and suggestions;

- Createa nation discussion through proper and consistent channels to advance the people' awareness towards education issues as a collective subject.

The results of this study is consistent with Valli and Buese's (2007) argument that role prospects 'increased, intensified, and expanded' in many aspects of teachers' work. Moreover, there is a similarity between what this study indicates about the relation between weakening teacher autonomy and the decline in teacher satisfaction and what many studies have indicated all over the world including Canada (Dinham and Scott, 1998, 2000, 2003), Cyprus (Zembylas, 2003), Malta (Bezzina, 2005), Pakistan (Malik et al., 2011) and in the UAE Ibrahim, AlKaabi\& El-Zaatari (2013) and Tabari (2014). Finally, the findings of the studyabout school leadership was aligned with Litz's, (2014) research about the 'Perceptions of School Leadership in the UAE', which indicates that the principals' 'assessment' about their approach is not consistent with what the majority of teachers believe. The perception on the teacher's role could be continued further by conducting a larger study in which more teachers, administrators and students could participate from different districts in the UAE. Moreover, further studies could collect qualitative data through planning visits to investigate directly the interaction between the teachers and the students. Finally, conduct a study to examine closely the impact of the cross-cultural feature of education in UAE schools as teachers from all over the world teach students belonging to different backgrounds and cultures.
This research has accomplished its intended aim to determine answers to the study question: whether the consecutive changes taking place locally and globally have affected the teachers' historical value and affected the role that the societies have assigned for them. The current study found that there is a need to believe that improving educationand empowering teachers' role is the most essential step for developing our societies. Today, educators in the UAE face huge pressures to improve the quality of education to the level of world standards. Improving education is not an option, but it is a necessity for societies that wish to be internationally recognized. Empowering teachers is not only a way of improving the lives of the teachers; it is a means to improving the entire society and the future of the UAE nation.

\section{References}

Akkari, A. (2004). Education in the Middle East and North Africa: The current situation and future challenges. International Education Journal, vol. 5(2), pp. 144-135.

Alam, G. \&Khalifa, T. (2009). The impact of introducing a business marketing approach to education: A study on private HE in Bangladesh. African Journal of Business Management, vol.3 (9), pp. 463-474.

Ball, S. J. (2003). The teacher's soul and the terrors of performativity. Journal of Education Policy, vol. 18 (2), pp. 215-228.

Ball, S. J. (2004). Education reform as social barbarism: Economism and the end of authenticity. The Sera Lecture 2004.

Barnett, W.S. (2003). Better teachers, better preschools: Student achievement linked to teacher qualifications. National Institute for Early Education Research, Issue 2.

Bartelett, L.,Frederick, M., Gulbrandsen, T. \& Murillo, E. (2002). The marketization of education: Public schools for private ends. Anthropology \& Education Quarterly, vol. 33(1), pp.1-25.

Bartelett, L. (2004). Expanding teacher work roles: a resource for retention or a recipe for overwork? Journal of Education Policy, vol. 19(5).

Beijaard, D., Meijer, P. C. \&Verloop, N. (2004). Reconsidering research on teachers' professional identity. Teaching and Teacher Education, vol. 20, pp. 107-128.

Bill \& Melinda Gates Foundation. (2012). Asking students about teaching: student perception surveys and their implementation. Seattle: policy and Practice Brief.

Braun, V. \& Clarke, V. (2006). Using thematic analysis in psychology. Qualitative Research in Psychology, vol. 3 (2), pp. 77-101.

Bray, M. \&Kwo, O. (2013). Behind the façade of fee-free education: Shadow education and its implications for social justice. Oxford Review of Education, vol.39, (4), pp. $480-497$.

Carr, L. T. (1994). The strengths and weaknesses of quantitative and qualitative research: what method for nursing? Journal of Advanced Nursing, vol.20, pp.716721.

Caruth, G. (2013). Demystifying Mixed Methods Research Design: A Review of the Literature. Mevlana 
International Journal of Education (MIJE) Vol. 3(2), pp. 112-122, 1 August, 2013.

Chan, K. W. (2005). In-service teachers' perceptions of teaching as a career: Motives and commitment in teaching. AARE International Education Research Conference. The University of Western Sydney.27th November to 1 st December.

Chua, A. L. (1995). The privatization-nationalization cycle: The link between markets and ethnicity in developing countries. Columbia Law Review, vol. 95 (2), pp. 223303.

Clarke, M. \&Otaky, D. (2006). Reflection 'on' and 'in' teacher education in the United Arab Emirates. International Journal of Educational Development, vol. 26, pp. 111-122.

Collie, R., Shapka, J. \& Perry, N.(2012). School climate and social-emotional learning: Predicting teacher stress, job satisfaction, and teaching efficacy. Journal of Educational Psychology [online] First Publication, July 16, 2012American Psychological Association. [Accessed 13Febrruary 2016].

Cotterall, S. (1995).Investigating learner beliefs: Readiness for autonomy. Pergamon, vol. 23 (2), pp. 195-205.

Creswell, J. W. (2009). Research design: Qualitative, Quantitative, and Mixed Methods approaches. $3 \mathrm{rd} . \mathrm{ed}$. California: SAGE Publications.

Crump, S. (2005). Changing times in the classroom: Teaching as a "crowed profession". International Studies in Sociology of Education. 2005 theme: teaching and learning in changing times. May 2005.

Cuban, L. (1984). How teachers taught: Constancy and change in American classrooms1890-1980. Virginia: Longman Inc.

Day, C. (1999). Developing teachers: The challenges of lifelong learning. London: Taylor \& Francis, Inc. Books.

Department of Anthropology and African Studies. (2008).The informal market of education in Egypt: Private tutoring and its implications. Mainz: Johannes Gutenberg-University.

DeWalle, N. (1989). Privatization in Developing Countries: A Review of the Issues. World Development. Vol. 17, No. 5, pp. 601-615, 1989.

Diallo, I. (2014). Emirati students encounter western teachers: Tensions and identity resistance. Cross Cultural Pragmatics Conference. University of East Anglia, UK, 29 June - 1 July.

Dinham, S. \& Scott, C. (1996). Teacher satisfaction, motivation and health: phase one of the Teacher 2000 Project. New York: ERIC.

Dinham, S.\& Scott, C. (1997). Modelling Teacher Satisfaction: Findings from 892 Teaching

Staff at 71 Schools: the Annual Meeting of the American Educational Research Association. Chicago. March 24$28^{\text {th }}$.

Dinham, S., \& Scott, C. (2002). Pressure points: school executive and educational change. Journal of Educational Enquiry, vol. 3(2), pp. 35-25.

Dubai Knowledge, ACTEVET, ADEC \& MoE. (2015).United Arab Emirates School Inspection Framework 2015-2016. Abu Dhabi: Dubai Knowledge, ACTEVET, ADEC \&MoE.
Dubai School of Government. (2009). The Hidden Gender Gap in Education in the UAE. Dubai: Dubai School of Government.

Dubai School of Government.(2010).Gender and nationality in the United Arab Emirates: A crisis for boys. Dubai: Dubai School of Government.

Eikenberry, A. M. \& Kulver, J. D. (2004). The marketization of the non-profitsector: Civil society at risk? Public Administration Review, vol. 64 (2), pp. 132-140.

Emmer, E. T. \&Stough, L. M. (2001). Classroom management: A critical part of educational psychology, with implications for teacher education. Educational Psychologist, vol.36 (2), pp.103-112.

Evans, L. (2008). Professionalism, professionality and the development of education professionals. British Journal of Educational Studies, vol.56 (1), pp. 20-38.

Farag, I. (1998). Educational debate in Egypt. ISIM Newsletter 1/98.

Finley, S. J. (2000). Instructional coherence: The changing role of the teacher. Austin, Southwest Educational Development Lab.

Flinders, D. J. (1988). Teacher isolation and the new reform. Journal of Curriculum and Supervision, vol. 4(1), pp. 17-29.

Fullan, M. (1994). Change forces: Probing the depths of educational reform. The Palmer Press (A member of the Taylor \& Francis Group).

Ghazi, S. R. (2012). Facet-specific job satisfaction and experience of elementary school head teachers in Pakistan. International Journal of Developing Societies, vol.1(4), pp. 159-168.

Glewwe, P. \& Kremer, M. (2006). Education in developing countries. Handbook of the Economics of Education, vol. 2, pp. 945-1008.

Hatherley-Greene, P.J. (2014). The Cultural Border Crossing Index: implications for higher education teachers in the UAE. Learning and Teaching in Higher Education: Gulf Perspectives, 11(2).

Harden, R. M. \& Crosby, J. (2000). The good teacher is more than a lecturer- the twelve roles of the teacher. Medical Teacher, vol. 22 (4), pp. 334- 347.

Hargreaves, A. (2000). Mixed emotions: Teachers' perceptions of their interactions with students. Teaching and Teacher Education, vol.16,pp. 811-826.

Hargreaves, A. (2002). Teaching in the knowledge society. Technology Colleges Trust Vision- 2020. [online]. Technology Colleges Trust. Second International Online Conference13-26 October and 24 November-7 December 2002. [Accessed 13 July 2015]. Available at:http://www.cybertext.net.au/tct2002/keynote/printable /hargreaves\%20-\%20printable.htm.

Hargreaves, A. (2004). Inclusive and exclusive educational change: emotional responses of teachers and implications for leadership. School Leadership \& Management, vol. 24(2), pp. 288-309.

Hargreaves, A. \& Goodson, I. (2006). Educational change over time? The sustainability and non-sustainability of three decades of secondary school change and continuity. SAGE Publications. Educational Administration Quarterly, vol. 42 (1), pp. 3-41. 
Hargreaves, A. (2007). Sustainable leadership and development in education: creating the future, conserving the past. European Journal of Education, vol. 42 (2), pp. 223-233.

Hill,G.W. \& Zinsmeister, D.D. (2011). Becoming an ethical teacher. Effective College and University Teaching. Available data/43586_14.pdf.

Hirtt, N. (2005). Marketization of education in the globalised economy. Worldwide Forum for Comparative Education, "Globalisation of Education: Government, Market and Society. Beijing Normal University, August 2005.

Hinchey, P. H.\& Cadiero-Kaplan, K. (2005). The future of teacher education and teaching: Another piece of the privatization puzzle. Journal for Critical Education Policy Studies, vol. 3, (2), pp. 1-19.

Holliday, A. (2002). Doing and Writing Qualitative Research. London: Sage Publications.

Hycner, R. H. (1985). Some guidelines for the phenomenological analysis of interview data.

Human Studies, vol. 8, pp. 279-303.

Ibrahim, A. S., Al-Kaabi, A., \& El-Zaatari, W. (2013). Teacher resistance to educational change in the United Arab Emirates. International Journal of Research Studies in Education, vol. 2 (3), pp. 25-36.

Ingersoll, R. (2001). Teacher turnover and teacher shortages: An organizational analysis. American Educational Research Journal, vol. 38(3), pp. 499-534.

Ingersoll, R. (2007). Short on power, long on responsibility. Educational Leadership, Vol. 65 (1), pp. 20-25.

Johnson, R. B.\& Onwuegbuzie, A. J. (2004).Mixed methods research: A research paradigm whose time has come. Educational Researcher, vol. 33(7), pp. 14-26.

Karkkainen, K. (2006). Emergence of private higher education funding within the OECD area. OECD Centre for Educational Research and Innovation.

Katja, V. \&Anneli, E. (2009). Vocational teachers in the face of major educational reform: Individual ways of negotiating professional identities. Journal of Education and Work, vol. 22 (1), pp. 15-33.

Kelchtermans, G. (2005). Teachers' emotions in educational reforms: Self-understanding, vulnerable commitment and micro political literacy. Elsevier: Teaching and Teacher Education, vol.21, pp.995-1006.

Knowledge and Human Development Authority. (2014). Inspection Handbook 2013-2014. Dubai: Knowledge and Human Development Authority.

Knowledge and Human Development Authority. (2013). The performance of private schools in Dubai. Dubai: Dubai Schools Inspection Bureau.

Kvale, S. (1996). Interviews: learning the craft of qualitative research interviewing. $3^{\text {rd }}$ ed. California: Sage Publications.

Leverhulme Centre for Market and Public Organisation. (2003). the role of incentives in the public sector: Issues and evidence. Bristol: Centre for Market and Public Organisation.
Litz, D. (2014). Perceptions of school leadership in the United Arab Emirates (UAE).Ph.D. Thesis. University of Calgary.

Loeb, S. \& Page, M. (2000). Examining the Link Between Teacher Wages and Student Outcomes. The Importance of Alternative Labor Market Opportunities and NonPecuniary Variation. The Review of Economics and Statistics, August 2000, 82(3): 393-408.

Mansour, A. (2008). The impact of privatization on the United Arab Emirates (UAE) Federal public sector. International Public Management Review electronic Journal [online] 2008 [Accessed 13July 2015]. Available at:http://www.ipmr.net. .

Malik, S., Iqbal, M., Khan, M., Nasim, K., Yong, J. \&Abbasi, M. (2011). Measuring job satisfaction, motivation and health issues of secondary school teachers in Pakistan. African Journal of Business Management, vol. 5(33), pp. 12850-12863.

Marsh,M. (2002). The shaping of MsNicholi: the discursive fashioning of teacher identities. Qualitative Studies in Education, vol. 15 (3), pp. 333 -347.

Mayer, D. (2006). The Changing Face of the Australian Teaching Profession: New generations and new ways of working and learning. Asia-Pacific Journal of Teacher Education, Vol. 34( 1), pp. 57-71.

Mayer, D., Luck, C. \& Luck A. (2008). Teachers' national regulation and cosmopolitanism. Critical Readings in Teacher Education[online] 2008, p. 79-98 [Accessed 19march 2016]. Available at http://hdl.handle.net/ 10536/DRO/DU:30019776.

McInerney, V. (2003). Multiculturalism in today's schools: Have teachers' attitudes changed over two decades: the Annual Meeting of the Australian Association for Research in Education. Auckland. November.

Melville, W., Bartley,A. \& Weinburgh, M. (2012). Change forces: Implementing change in secondary school for the common good. Canadian Journal of Educational Administration and Policy, vol. 133, pp. 1-26.

Ministry of Education, (2010). The ministryof education strategy 2010-2020. Abu Dhabi: Ministry of Education.

Mockler, N. (2011). Beyond 'what works': Understanding teacher identity as a practical and political tool. Taylor \& Francis in Teachers and Teaching: Theory and Practice.

Morgan, G. A. \& Harmon, R. J. (1999). Research questions and hypotheses. J. AM. ACAD. CHILD ADOLESC. PSYCHIATRY. [online] FEBRUARY 2000, p. 261-263.

Murnane, R., Willett, J. \& Singer, J. (1989). The influences of salaries and "opportunity costs" on teachers' career choices: Evidence from North Carolina. Harvard Educational Review, vol. 59 (3), pp. 325-346.

National Qualification Authority. (2013). The UAE education system. Overview of Performance in education. Abu Dhabi: National Qualification Authority.

Onwuegbuzie, A. J. \& Leech N. L. (2006). Linking research questions to mixed methods data analysis procedures. The Qualitative Report, vol. 11 (3), pp. 474-498.

Pelletier, L., Le'vesque, C. \& Legault, L.(2002). Pressure from above and pressure from below as determinants of 
teachers' motivation and teaching behaviours. Journal of Educational Psychology, vol. 94 (1), pp. 186-196.

Raven, J. (2011). Word Emiratizing the education sector in the UAE: Contextualization and challenges. Emerald Group Publishing,

Crown Centre of Middle East Studies. (2009). The Politics of higher education in the Middle East: problems and prospects. Marseille: Middle East Briefs.

Sanyal, B. C. (1998). Diversification of sources and the role of privatization in the Arab States region. World Conference on Higher Education. 5-9 October.

Scott, C., Stone, B. \&Dinham, S. (2001). "I love teaching but...." International patterns of teacher discontent. Education Policy Analysis Archives, vol. 9 (28), pp. 118.

Sheikh Saud bin Saqr Al Qasimi Foundation for Policy Research. (2014). Education reform in the UAE: An investigation of teachers' views of change and factors impeding reforms in Ras Al Khaimahschools. Ras AlKhaimah: Sheikh Saud bin Saqr Al Qasimi Foundation.

Sidani, Y.\&Thornberry, J. (2010). The current Arab work ethic: Antecedents, implications, and potential remedies. Journal of Business Ethics, vol. 91 (1), pp. 35-49.

Skaalvik, E. M. \&Skaalvik, S. (2007). Dimensions of teacher self-efficacy and relations with strain factors, perceived collective teacher efficacy and teacher burnout. Journal of Educational Psychology, vol. 99. (3), pp. 611-625.

Temin, P. (2002).Teacher quality and the future of America. National Bureau of Economic Research. Massachusetts: Working Paper No. 8898.

Tsui, A. B. M. (2007). Complexities of identity formation: A narrative inquiry of an EFL teacher. TESOL Quarterly, vol. 41(4), pp. 657-680.

UAE National Charter 2021. (2015). Vision 2012. Dubai: UAE National Charter2021.

Valli, L. \& Buese, D. (2007). The changing roles of teachers in an era of high-stakes accountability. American Educational Research Journal September 2007, vol. 44, (3), pp. $519-558$.
Vassallo, B. (2007). What makes them still tick: A study of job (dis) satisfaction among long serving teachers in Malta. The Online Journal of New Horizons in Education, vol. 4, (1) [Accessed 7 October 2015]. Available at: brian007@maltanet.net.

Walkington, J. (2005). Becoming a teacher: encouraging development of teacher identity through reflective practice. Asia-Pacific Journal of Teacher Education, vol. 33, (1), pp. 53-64.

Walle, N. (1989). Privatization in developing countries: A review of the issues. World Development, vol. 17 (5), pp. 601-615.

Wenger, E. (2010). Communities of practice and social learning systems: the career of a concept. Communities of practice and social learning systems [online] (n.d.), p. 1-16. [Accessed 5 February 2016].

Whitebook, M., Howes, C. \& Phillips, D. (1989). Who cares? Child care teachers and the quality of care in America. New York: Carnegie Corp.

Wood, P. \& Carlyle, D. (2002). Teacher identities under stress: The emotions of separation and renewal. Rutledge. International Studies in Sociology of Education, vol. 12 (2), pp. 169-189.

Woods, P. \&Jeferey, B. (2002).There construction of primary teachers' identities. British

Journal of Sociology of Education, vol. 23(1) pp. 89-106.

Zembylas, M. (2005). Interrogating "teacher identity": Emotion, resistance and self- formation. Educational Theory, vol. 53 (1), pp. 107-127.

Zembylas, M. \& Papanastasiou, E.(2005). Modellingteacher empowerment: The role of job satisfaction. Educational Research and Evaluation, vol. 11(5), pp. 433 - 459.

Zembylas, M. \& Papanastasiou, E. (2006). Teacher job satisfaction in Cyprus: The results of mixed-methods approach. Inter college: Cyprus.

\section{How to cite this article:}

Sahar Mahmoud El Ayouby and Solomon Arulraj David.2017, PErceptions on Teaching Profession and Changing Role of School Teachers: An Investigation from Eight Schools in Dubai And Sharjah. Int J Recent Sci Res. 8(4), pp. 16541-16549.

DOI: http://dx.doi.org/10.24327/ijrsr.2017.0804.0168 